\title{
Massim mortuary rituals revisited
}

John Liep

\section{Q OpenEdition \\ Journals}

Electronic version

URL: http://journals.openedition.org/jso/802

DOI: $10.4000 /$ jso.802

ISSN: $1760-7256$

\section{Publisher}

Société des océanistes

\section{Printed version}

Date of publication: 1 June 2007

Number of pages: 97-103

ISBN: 978-2-85430-010-9

ISSN: 0300-953x

\section{Electronic reference}

John Liep, « Massim mortuary rituals revisited », Journal de la Société des Océanistes [Online], 124 | Année 2007-1, Online since 01 June 2010, connection on 20 April 2019. URL : http:// journals.openedition.org/jso/802 ; DOI : 10.4000/jso.802 


\section{Massim mortuary rituals revisited}

par

John LIEP*

\section{RÉSUMÉ}

Alors que la région est célèbre pour la kula, les rites et échanges funéraires sont en fait la principale dimension culturelle des Massim - l'archipel juste à l'est de la Nouvelle-Guinée. Frederick Damon note que l'exhumation et l'enterrement secondaire, le thème central chez Robert Hertz, faisaient partie des rites mortuaires des Massim, mais furent interdits par le gouvernement colonial et par les missions chrétiennes, et ont disparu depuis longtemps. Les festivités mortuaires demeurent néanmoins essentielles dans les sociétés des Massim. Mon article étudie les autres aspects des rites mortuaires qui continuent d'en faire une préoccupation d'importance dans la région; et j'examine les échanges mortuaires de nourriture, d'objets de valeur indigènes et, de plus en plus, de marchandises et d'argent. J'insiste sur le fait que les échanges mortuaires font partie de cycles d'alliances matrimoniales qui s'étendent sur trois générations au moins et sont des moments de confrontation dans les pratiques de constitution de relations sociales et dans l'économie politique des sociétés locales. Ils demeurent donc importants dans ce secteur.

MotS-CLÉS : Massim, festivités mortuaires, échange

I had the good fortune to participate in the two Kula conferences around 1980 which, I believe, made some contribution to the ethnographic fame of the Massim. From the time of Seligman and Malinowski this relatively small subregion has yielded formidable material for anthropological discussion and has in the second part of the last century drawn quite a number of students so that it is now one of the most

\section{ABSTRACT}

While this region is famous for the kula, mortuary rituals and exchanges are in fact the prime cultural focus of the Massim - the archipelagos just east of New Guinea. Frederick Damon notes that exhumation and secondary burial, the theme central to Robert Hertz, were part of Massim mortuary rites, but were prohibited by the colonial government and Christian missions and have long disappeared. Yet mortuary feasting remains vital in Massim societies. My article examines what other aspects of mortuary rituals still make them a main concern in the region; and discusses mortuary exchanges of food, indigenous valuables and, increasingly, commodities and money. I will emphasize that mortuary exchanges are part of cycles of marriage alliances that span at least three generations and are moments of showdown in the practice of forming social relations and the internal political economy of local societies. Therefore, they remain so important in the area.

KeYwORDs: Massim, mortuary feasting, exchange

well studied anthropological regions in the world.

I have taken this opportunity to return to Massim mortuary rituals. The anthology Death rituals and life in the societies of the Kula Ring (Damon and Wagner, 1989) that resulted from the Second Kula conference's session on death rituals contained a number of informative ethnographies of this topic in various Massim

* University of Copenhagen, liep@get2net.dk 
societies. It did not, however, constitute a conclusive exploration of Massim mortuary rites. This was in part due to the absence of chapters by participants who, before and after the conference, contributed some of the most innovating analyses of this domain (Weiner, Munn and Battaglia). Neither does my article here pretend to present some definitive explanation of the Massim mortuary complex. It is only a modest attempt to outline what I find are some important aspects of it. I have drawn upon the Death rituals volume, but also on earlier and subsequent work on the theme from the region.

My perspective is in some way that of an insider-outsider. My fieldwork experience is from Rossel Island, the far-off easternmost island in the region, marked off from the rest by the Non-Austronesian language of its population ${ }^{1}$. However, Rossel shares matrilineal descent with most of the Massim and other features point to considerable Austronesian cultural influence. The mortuary ritual on Rossel is much downsized compared to that of the remainder of the Massim. There is now only a single mortuary feast shortly after the funeral, cantering on exchanges between the 'sides' of the deceased, the deceased's spouse and the deceased's father. Here is mortuary ritual cut down to the bare bones, so to speak. The whole collection of food distributions so characteristic of the Massim is absent. In some way this was a piece of luck. Presented with a simplified model of the "elementary structures' of mortuary exchanges, and undisturbed by the bewildering overlay of innumerable other exchanges and rites, I was from early on impressed with the transgenerational aspect of mortuary rituals. This has made me keen to distinguish it in the much more complex material from other Massim societies. I cannot pretend to master this extensive material in depth, but have attempted to draw out some more general patterns and illustrate them with simplified case material. I hope this may be helpful in further comparative work on mortuary rites in other regions.

\section{Fear and loathing in the Trobriands: Malinowski on death}

'The whole mortuary ritual is', Malinowski wrote, 'perhaps the most difficult and bewildering aspect of Trobriand culture for the investigating sociologist' (1929: 148). In fact he published about 'mortuary practices in their barest outline only. A complete account of them would easily fill a volume of the present size' [the volume of The sexual life of savages] (ibid.: 149). What he did describe conformed to the theme of Robert Hertz's essay on Death (1960 [1907]). This was the sequence of rites from death and exhumation to secondary burial and briefly to the end of the cycle of mortuary feasts. Like Hertz, Malinowski was concerned with the transformation of the social individual after death and its repercussions on the living. Malinowski described what to him was the bizarre customs of laying all the onerous and gruesome obligations of mourning not on the deceased's 'real' matrilineal relatives, but on the spouse and the affines (including, for a man, also his children). He noted, as did Hertz, a correspondence between the decaying state of the corpse and the 'social death' of the mourners, set apart from the living by enervating taboos, as well as their 'rebirth' to normal life at the ceremonial lifting of the taboos. Malinowski only departed from Hertz's interpretation when he asserted that all the mortuary rites proceeded without consequence for the deceased's spirit. It was transported into the land of the dead shortly after death and living happily there; unconcerned with the prolonged mortuary tasks of the living. Montague argues that Malinowski was mistaken here. The spirit is well able from the nether world (Tuma) to appreciate the rites honouring him or her, she says (Montague, 1989: 28).

Malinowski probably gave up writing an exhaustive analysis of Trobriand mortuary rites because he was unable to create a theoretical scheme that could account for them. This was due to his lack of interest in kinship analysis and a weak sense of social structure. His main involvement was with the individual and with psychological problems. He therefore delved into the aspects which concerned his own personality the most, the fear of death and the burden of bereavement, and how they were played out in the strange orchestration of a matrilineal culture. In a way, also Hertz's discussion in his essay centred on the individual. Hertz was at pains to emphasize that death was a 'social fact' and the individual a 'social person'. 'Society' both determined conceptions of the person and the soul, but also the state of the living during the liminal period of transition after death. But his Durkheimian conception of 'society' was very abstract and unconcerned with the differentiation and relationships of its parts.

1. During a short visit to the Trobriands in $1980 \mathrm{I}$ had the opportunity of attending a women's sagali at the village of Sinaketa, but I did not attempt to record it. 


\section{Weiner's discovery of the function of Trobriand mortuary rites}

Annette Weiner must have the full credit of a number of significant advancements in the understanding of Trobriand mortuary rites that contributed greatly to further research on these rites in the region (Weiner, 1976; 1978; 1980). First, she showed that social relationships are produced through exchanges. These are not titfor-tat reciprocity but long term projects where individuals detach resources from themselves and use them to attach other people into relationships. Second, she argued that these gifts and relationships must be seen in terms of a reproductive model of society. They are part of cycles of reproduction that transcend the life of individuals. Finally, she demonstrated that mortuary rituals were the key to understand these cycles.

Weiner also made a striking ethnographic discovery when she found out that women's wealth of fibre skirts and bundles played an important role in the Trobriand mortuary cycle, especially in large prestations at a special women's mortuary feast or sagali. This was a domain that Malinowski had totally neglected. I must say, however, that in my opinion Weiner's feminist agenda led her to overexpose the importance of women's wealth and underexpose that of male valuables and prestations. Although women undoubtedly have a prominent role in some of the Trobriand mortuary ceremonies and in society on the whole she aggrandized female power unduly. This led her to unfortunate misinterpretations that may have stood in the way of the recognition of her unquestionable merits ${ }^{2}$.

Let me present a brief summary of what I regard as the most valuable insights in Weiner's interpretation of Trobriand mortuary rituals.

When a person dies all the relationships that centred on the deceased are disrupted. The function of mortuary exchanges is to regenerate the social fabric and reconstitute the web of social relations. Mortuary ritual resolves the social crisis brought on by death. The regeneration of social relationships is not easy work. Death is virtually always the result of somebody's sorcery. It does not only cause sorrow but also fear and rage. It takes time to reconcile the survivors. Mourning duties are hard and protracted, they are remunerated by prestations of wealth, as is the care the deceased took for other people, and they for him or her. In a long sequence of mortuary exchanges dragging out for years relations among the living are repaired. This prolonged negotiation about social relations cannot proceed just verbally. It must be substantiated by lavish and repeated gifts of valuable objects. Further, mortuary feasting may be expanded by the power plays of important leaders. In the densely populated and fertile northern parts of Kiriwina, the main Trobriand Island, where the group structure is complicated by social hierarchy, mortuary ritual and exchanges are especially elaborate and participation extensive. It was Weiner's accomplishment to make sense of what to Malinowski seemed an 'overgrowth of ceremonial' (1929: 148).

Weiner made clear what is at stake at mortuary rites. She took as point of departure the Trobriand matrilineage (dala). Its members are united by the common substance of blood transferred through lineage women, and spirits reincarnated from lineage ancestors. It has a recognized headman or chief. Further, it has control over a number of resources of material and symbolic property. They consist of plots of land, a hamlet site and a stock of lineage names, body and house decorations, magic texts, dances and distinctions of rank. At death, when people return to a spirit life in the other world, they become 'pure dala', but in this world neither the lineage nor individuals can exist autonomously. They are continuously engaged in relationships with 'others' in other lineages. While a man's children belong to a lineage different to his own he nevertheless 'forms' them from infancy through his gifts of food, a name, and later decorations. He gives his sons magic and use right to his land; he gardens for his daughter whose marriage he arranges. In this way he produces filiation as a social relationship. Not only himself but also his lineage is involved in these rela-

2. Weiner argued that the asymmetrical relationship between affines which is at the basis of Trobriand harvest prestations and thereby the political economy and hierarchy is in fact guided by equivalence. (She later published a pertinent critique of the principle of reciprocity (1980), but did not heed it here.) Men's harvest prestations to their brother's in law, even when they are chiefs, are not 'tribute' as Malinowski had called it (1929: 81), she asserted (Weiner, 1976: xvii, 202). They are repaid by prestations of women's wealth by the men's sisters, supported by their husbands, to the women's lineages' mortuary prestations (1976: 197-98). As chiefs also must contribute women's wealth to their wives they are subjected to the same levelling obligations. This interpretation did only contribute to confusion about Trobriand hierarchy and the power and awe of chiefs. Women's fibre bundles in fact constitute an internal form of small cash that may be exchanged for a wide range of internal and imported goods It has developed into a local money form that has inflated much during the Twentieth century at the cost of a heavy burden of female labour (Weiner, 1980b). Its expansion must be understood as a an internal counter reaction to the rising penetration of money in Trobriand life and decreasing access to male valuables from external trade (see also Liep, 1990) 
tionships. They are often made so strong that sons may continue to reside in their father's hamlet after his death, exercising land use rights and supporting their father's lineage's exchanges. Similarly a daughter may 'take the place of the father' and contribute to his lineage women's' distributions.

Thus, of a lineage's stock of property a large part is continually invested in others maintaining valuable supporting relationships. At death these investments and relationships are compromised and must be resorted. Weiner put most emphasis on the reconstitution of relationships, for example in the binding that a lineage can effect by bestowing relics of the deceased on affines and filiates to carry, sometimes for years. Further, relationships with lineage filiates would be kept up by extending land use rights and accepting continuing mutual support in exchanges. But Weiner also noted the necessity to reclaim for example lineage names and land through payments after a death to prevent their loss and return these resources into lineage control. Finally, among the numerous Kiriwinan mortuary exchanges she briefly described the kalakeyala kapu, a large presentation of male and female valuables, as well as money and calico, to the deceased father's lineage in honour of all he gave to the child (1976: 114). Although Weiner did not say this comparative evidence from the Massim (Damon, 1989; Battaglia, 1985; Liep, 1989; Munn, 1986: 177) indicates that this prestation in fact ends the relationship established through filiation between the two lineages, the deceased's father's and the deceased's own - with respect to this particular child. When all the father's children with the same wife are dead the relationship between the two lineages is closed in terms of this marriage.

Mosko has argued that instead of regenerating social relationships, as was the thrust of Weiner's interpretation, Trobriand mortuary rituals are about 'de-conception' and undoing relationships (1985: 221). In fact, there is no paradox here. Relationships between lineages related through marriage are reconstituted at the death of each of the spouses, proceed into the following generation, and are cut at the deaths of the children of the marriage. There is both regeneration and closure, but from different generational perspectives in the mortuary rituals. Thus the marriage cycle spans two generations. We may take two further circumstances into account. Marriage exchanges are arranged by the (lineages of) the mother and father of the groom as well as those of the bride. Besides, among members of a deceased's own lineage, that conduct the final payment, and those of the father's lineage, that receive it, juniors of the generation following the deceased's will often participate in the exchange. This shows that a marriage alliance may in fact involve four generations and several lineages.

\section{Mortuary rituals in the wider Massim}

Inspired by Weiner's breakthrough in the Trobriands a topic of the Second Kula Conference in 1981 was exactly mortuary rites. In his introduction to Death rituals and life in the societies of the Kula Ring (1989) Fredrick Damon argued that 'No description of any single Massim society, and no understanding of the region as a whole, can approach completeness until these rituals are understood' (1989: 3). And in fact in most Massim societies the mortuary complex is the central cultural focus which occupies a considerable part of people's energy and resources. Damon touched in passing on a significant fact. He noted that secondary interment was formerly practiced throughout the region, but no longer is and 'many of us learned little about it' (ibid. : 10). (It was prohibited early in the 20th century by the colonial government.) The very aspect that was at the front of the interest of Hertz and Malinowski has thus been obliterated. Its seems also that the adoption of Christian beliefs about death, the soul and resurrection have confused or eroded many former indigenous conceptions (Macintyre, 1989). But still mortuary exchanges flourish. This means that mortuary rites carry out a number of other functions that are still pertinent to Massim populations. My summary of Weiner's interpretation of the rites in Kiriwina has brought these to the foreground.

The editors of Death rituals and life wanted to highlight difference and variation between Massim societies. There are a number of differences which Wagner attempted to systematise in a structural model in his conclusion (Wagner, 1989). They concern the number and ceremonial purposes of the collection of mortuary feasts, the roles of those who are the undertakers (often paternal relatives) and public mourners, the severity and length of mourning obligations, the direction of various prestations and the relative weight of various kinds of objects of wealth in the exchanges. These value objectifications are raw and cooked food; pigs; in some societies female wealth such as skirts and fibre bundles; traditional male valuables, some of which also circulate in the kula; and money and trade goods. In this article I am more concerned with 
the similarities across the Massim. I also bypass the aspect that in some peripheral Massim societies mortuary rites are either of recent importation (Young, 1971: 232-33 for Kalauna, Goodenough Island) or they are relatively reduced (Liep, 1989 for Rossel).

The general scheme is a number of rituals that feature the funeral and the laying on of mourning taboos that at first cover the whole community, but are subsequently lifted, stage by stage, leaving the spouse and close affines to become 'free' last. In these stages prestations are performed that compensate the deceased's lineage relatives for their loss and soothing the suspicion of sorcery by the affines; mourners may be remunerated, and the earlier support of widespread relatives is acknowledged. There is no doubt that the motive of reconstructing social relationships after the death is prominent throughout the Massim. But I suggest that the closure of formal inter-lineage relationships at the death of children of a marriage is widespread, although few contributors to Death rituals were aware of this structural aspect. If this is the case it shows some stability to Crow type marriage structures that are found in a number of Massim societies. They are not in fact of the 'aleatory' nature that LéviStrauss (1969: xlii) suggested, but imply longterm alliances spanning at least two generations, after which new marriages may re-establish lineage connections anew. The discontinuation of affinal ties may begin already at the death of one of the spouses in a marriage. This is especially the case in those d'Entrecasteaux societies where matrilineage identity and autonomy is most emphasized, where affines are regarded as at best a necessary evil, and where they ideally are banned from the deceased's hamlet after his or her death (Fortune, 1932; Thune, 1989; but see Kühling, 1998 for qualifying evidence). But final severance of the alliance can only take place at the death of the children of the marriage ${ }^{3}$.

A number of other aspects are relevant to Massim mortuary rites. The prestations at them may decide the possession or loss of land and residence rights (Weiner, 1976: 43, 163-67; Berde, 1979; Damon, 1983b; Macintyre, 1983; Liep, 1983; Battaglia, 1990: 103-04; Lepowsky, 1993: 270). This is extremely important, considered that it has been almost a dogma among anthropologists that land in Melanesian societies is inalienable (see for example the very influential Gregory, 1982: 44, 164). It is maybe the most significant discovery of anthropological study of Massim mortuary ritual although not realised by the editors of Death rituals. In fact, actual use and possession of land may lead to change of ownership if the land is not adequately reclaimed. Further, there may be contention about the burial site of a spouse which may determine the future residence and allegiance of children (Berde, 1974: 164-65; Damon, 1983b). With population increase and mounting pressure on land resources the close connection between mortuary prestations and the distribution of land rights can only lead to the expansion of mortuary feasting. Finally, the last stage in the mortuary feast sequence is usually a 'great feast' honouring all the dead of a lineage during a period of a number of years. This potlatchtype event demands much effort to accomplish as it requires huge resources of vegetable food and pigs. Its successful undertaking is an important step in the career of big men and a demonstration of the strength and external support of lineages. All these factors together explain why mortuary feasting is still vital in the Massim. Because inter-lineage relationships are so important and widespread people are linked to a number of lineages. In many Massim societies it is a standing obligation for affines and filiates of a lineage to contribute to its mortuary prestations. Therefore, participation in mortuary exchanges is a recurrently activated duty that involves people time and again.

\section{Mortuary rites and forms of wealth}

We have been asked at this session to consider the question of what part destruction plays in the transition of the deceased to the other world and in this connection the contrast between perishable flesh-type objects and durable bonelike objects. I think that in the context of the Massim deconstruction may be a more significant theme than destruction. True enough, there are elements of destruction in the mortuary rites of Massim societies. People cut down trees in the deceased's hamlet and may damage his possessions and his house in the havoc wrought at the chaos of death. In the Trobriands the deceased's yam house is pulled down. In some societies various articles, even valuables, may be buried with the deceased. The crops of the deceased's gardens and his or her pigs are usually used up in the mortuary distributions. But in the manifold phases and exchanges in Massim mortuary

3. In the Trobriands and on Rossel Island there is even a preference for classificatory (minimally second cousin) patrilateral marriage that renews marriage ties between lineages or clans. 
cycles the aspect of destruction seems relatively minor.

The concrete individual represents the intermingling of paternal and maternal forces and substances and of the lineages of the two parents. At marriage the individual is involved in further intermingling, producing children with a spouse that often is from a third lineage. It seems that at least some Massim societies in various ways ritually attempt to disassemble these various influences and involvements in a kind of symbolic post mortem and redirect them as parts to their various origins.

The best example of this process has been researched by Battaglia for the Sabarl in the Calvados Chain of the Louisiade Archipelago (1983; 1985; 1990; 1992). The Sabarl have a very clear-cut conception theory of the person. During intercourse 'white blood' (semen) from the father and red blood from the mother mingle and form the embryo. The 'white blood' produces the white parts of the body; the fat and the bones. The red blood becomes the meat and blood of the baby. As a child grows, the father, and later his representative, a paternal crosscousin 'father', gives the child (and wider his or her lineage) growth sustaining things: the fat meat of young coconuts, sago pudding enriched with the fat cream of coconut, pigs, and ceremonial stone axes, the latter quintessentially masculine and 'greasy'. From the mother's side the child is nurtured with yams. Different parts of the body are thus further produced by complementary paternal and maternal foods and valuables. An important aspect of the work of mortuary rituals is the deconstruction of the person, the separation of the parts, and the symbolic return to the paternal side of its life-contribution to the person of the deceased. Pigs and sago pudding figure conspicuously in the prestations to the ceremonial 'father' that 'finish' the deceased. An effigy is built out of hafted stone axes, which are thereupon presented to the 'father' and his lineage kinsmen. When they have 'eaten' these things the paternal aspect of the deceased, as well as the formal alliance between the lineages of the father and mother, is obliterated.

We see here how different kinds of objects, their qualities and origin are used to conceptualise social relationships and the production and reproduction of people as well as dissolution of persons and relationships. This comes out very clearly in the Sabarl case. Regrettably, comparative material from other Massim societies is fragmentary and at the best tentative. Other researchers have not attempted to delve as deeply in this symbolic domain as Battaglia. Further, such symbolic constellations could be quite different or much less well structured in other societies. Local symbolic conceptions are the products of disparate historical processes and may lead to quite dissimilar results. I just mention that on Tubetube, west of Sabarl in the Engineer Group, bones are believed to be solidified mother's milk (Macintyre, 1989); while on Muyuw (Woodlark Island) in the northern Massim the whole person derives from the father because he produces all the food that flows into the foetus. The mother is only a vessel for the growing child (Damon, 1989b). This shows how three societies, all matrilineal, have developed very contrasting theories of personhood.

It is obvious that the character of the various objects that appear as customary mortuary gifts lends them different symbolic potential. Food items are relatively perishable. Yet food is highly valued and the ability to grow more than sufficient is a foundation of self-esteem. But to make an impression, food must usually be presented in bulk. Pigs, of course, represent concentrated food and work in raising them. In the smaller island they are often procured for mortuary feasting through trade connections. Pigs, therefore, are highly valuable and usually appropriated by men for their public presentations. Again, there is a difference between on the one side, cooked food and slaughtered pigs, that can only be consumed, and on the other, raw yams and live pigs that may be exchanged again to sustain further relationships. Still raw food and pigs must sooner or later be consumed. There is a limit to their recycling potential. Again, women's fibre wealth, Weiner's publicity campaign notwithstanding, is often of low unit value and relatively perishable. Its symbolic carrying capacity is correspondingly limited.

The most indestructible forms of wealth are 'male' valuables of shell and stone. Some of these are ancient heirlooms, associated with mythical heroes and former owners who are now ancestors. They may be exchanged again and again through generations and acquire an aura of eternity and sacredness. When somebody is dying, especially an important person, these treasures are displayed on and around the body, and when the soul passes into the other world it takes them along in their spiritual aspect. Exchanged in mortuary prestations these valuables for years become icons of deceased for whom they 'paid'. This 'hard' wealth thus is the most precious of the things exchanged at mortuary feasts.

As various wealth items have different physical and symbolic capacities they also refer to 
domains of different extension. Women's wealth is thus associated with the domestic sphere; garden food with the surrounding land of the ancestors. Male valuables pertain to a much wider domain of regional exchange and connections. Shell ornaments and ceremonial axes often circulate in inter-island partnership trade, the most prestigious male sphere of action. For mortuary prestations they are often solicited from abroad. This gives these durable wealth objects an additional dimension of force and prestige.

I find no paradox, then, in the incorporation in most Massim societies of 'modern' commodities (trade goods) and money in 'traditional' mortuary prestations. These ceremonials have engaged the whole spectrum of indigenous wealth for an unknown past. There is nothing strange in that they should also involve alternative sources of wealth that have now been familiar in people's everyday life through several generations. Money and industrial products connote even farther origins and connections than traditional male wealth. There are only two factors that may prevent this new wealth from acquiring a more prominent place in mortuary exchanges. One is that traditional power holders may prevent it access to at least the more important mortuary prestations. Where local big men exercise control over the disposition of traditional wealth they may want to prevent upstarts from gaining influence by introducing modern wealth into the mortuary exchange field. (This is the case on Rossel Island [Liep, 1989; 1999]). The other factor limiting the flow of money and trade goods in mortuary exchanges is that Massim peoples are generally poor. Island residents do not possess the ability to dispose of large amounts of money or things that must be bought with money. Such contributions would mainly derive from migrants with salaried employment outside the region. I would expect, however, that on Misima Island, which during the last decade of the last century experienced a massive rise in local income from gold mining, a considerable part of this wealth was directed into mortuary feasting (Macintyre \& Foale, 2004).

\section{Conclusion}

I hope that I have been able to show that, all the variations and transformations between Massim localities notwithstanding, there are some general patterns that should be recognized and may be worthwhile to note in further comparative studies of death and mortuary rituals. I emphasize once again the need for a long time perspective that acknowledges that death is only a moment in a marriage alliance that lasts beyond the death of the partners in marriage into the next generation. Further, mortuary rites and exchanges, the central cultural events of most Massim societies, constitute showdowns in local social, political and economic relations. They have significant consequences for the distribution of vital resources and alignments of people.

I believe, therefore, that I have demonstrated that although the original questions raised by Hertz and Malinowski could no longer be well researched in the Massim in the late twentieth century there was a lot of other significant processes concerned with death that could. The project of transforming the dead and transporting him or her to the other world is not the only project of mortuary rites. They are concerned also with a number of other projects of continuing vital consequence for the living.

\section{BIBLIOGRAPHY}

Battaglia Debbora, 1983. Projecting Personhood in Melanesia: The Dialectics of Artefact Symbolism on Sabarl Island, Man 18, pp. 289-304.

_ , 1985. "We Feed our Father": Paternal Nurture among the Sabarl of Papua New Guinea, American Ethnologist 12, pp. 427-441.

-, 1990. On the Bones of the Serpent: Person, Memory, and Mortality in Sabarl Island Society, Chicago, The University of Chicago Press.

- 1992 . The body in the gift: Memory and Forgetting in Sabarl Mortuary Exchange, American Ethnologist 19, pp. 3-18.

Berde Stuart, 1974. Melanesians as Methodists, Ph. D. thesis, University of Pennsylvania.

—, 1979. The Impact of Christianity on a Melanesian Economy, in G. Dalton (ed.), Research in Economic Anthropology 2, pp. 169-187.

Chowning Ann, 1989. Death and Kinship in Molima, in F. H. DAmon and R. WAGner (eds.), Death Rituals and Life in the Societies of the Kula Ring, DeKalb, Northern Illinois University Press, pp. $97-$ 129.

DAMON Frederick H., 1989a. Introduction, in F. H. Damon and R. WAGner (eds.), Death Rituals and Life in the Societies of the Kula Ring, DeKalb, Northern Illinois University Press, pp. 3-19.

- 1989b. The Muyuw Lo'un and the End of Marriage, in F. H. DAMON and R. WAGNER (eds.), Death Rituals and Life in the Societies of the Kula Ring, DeKalb, Northern Illinois University Press, pp. 7394. 
DAmon Frederick H. and Roy WAGNER (eds.), 1989. Death Rituals and Life in the Societies of the Kula Ring, DeKalb, Northern Illinois University Press.

Digim'rina Linus, 1995. Gardens of Basima, Ph.D. thesis, Canberra, Australian National University.

Fortune Reo F., 1932. Sorcerers of Dobu, London, Routledge.

Gregory Chris A., 1982. Gifts and Commodities, London, Academic Press.

Hertz Robert, 1960 [1907, 1909]. Death and the Right Hand, London, Cohen and West.

KüHLING Susanne, 1998. The Name of the Gift: Ethics of Exchange on Dobu Island, Ph.D. thesis, Canberra, Australian National University.

LePowsky Maria, 1993. Fruit of the Motherland, New York, Columbia University Press.

LÉvi-Strauss Claude, 1969. The Elementary Structures of Kinship, London, Eyre and Spottiswoode.

LIEP John, 1989. The Day of Reckoning on Rossel Island, in F. H. DAMON and R. WAGNER (eds.), Death Rituals and Life in the Societies of the Kula Ring, DeKalb, Northern Illinois University Press, pp. 230-253.

_, 1991. Great Man, Big Man, Chief: A Triangulation of the Massim, in M. GodeliER and M. STRATHERN (eds.), Big Men and Great Men: Personifications of Power in Melanesia, Cambridge, Cambridge University Press, pp. 28-47.

_, 1999. Pecuniary Schismogenesis in the Massim, in David AkIn and Joel RobBIns (eds.), Money and Modernity: State and Local Currencies in Melanesia, Pittsburgh, University of Pittsburgh Press, pp. 131-150.

Macintyre Martha, 1989. The Triumph of the Susu: Mortuary Exchanges on Tubetube, in F. H. DAMON and R. WAGNER (eds.), Death Rituals and Life in the Societies of the Kula Ring, DeKalb, Northern Illinois University Press, pp. 133-152.
Macintyre Martha and Simon Foale, 2004. Politicized Ecology: Local Responses to Mining in Papua New Guinea, Oceania 74, pp. 231-251.

Malinowski Bronislaw, 1929. The Sexual Life of Savages in North-Western Melanesia, London, Routledge and Kegan Paul.

Montague Susan P., 1989. To Eat for the Dead: Kaduwagan Mortuary Events, in F. H. DAmon and R. WAGNer (eds.), Death Rituals and Life in the Societies of the Kula Ring, DeKalb, Northern Illinois University Press, pp. 23-43.

Mosko Mark, 1985. Quadripartite Structures: Categories, Relations, and Homologies in Bush Mekeo Culture, Cambridge, Cambridge University Press.

Munn Nancy D., 1986. The Fame of Gawa, New York, Cambridge University Press.

Thune Carl E., 1989. Death and Matrilineal Reincorporation on Normanby Island, in F. H. DAMON and R. WAGNer (eds.), Death Rituals and Life in the Societies of the Kula Ring, DeKalb, Northern Illinois University Press, pp. 153-178.

Wagner Roy, 1989. Conclusion: The Exchange Context of the Kula, in F. H. DAmon and R. Wagner (eds.), Death Rituals and Life in the Societies of the Kula Ring, DeKalb, Northern Illinois University Press, pp. 254-274.

Weiner Annette A., 1976. Women of Value, Men of Renown: New Perspectives in Trobriand Exchange, Austin, University of Texas Press.

-, 1978. The Reproductive Model in Trobriand Society, Mankind 11, pp. 175-186.

—, 1980a. Reproduction: A Replacement for Reciprocity, American Ethnologist 7, pp. 71-85.

_, 1980b. Stability in Banana Leaves: Colonization and Women in Kiriwina, Trobriand Islands, in M. Etienne and E. LeAcock (eds.), Women and Colonization, New York, J.F. Bergin, pp. 270-293.

Young Michael W., 1971. Fighting with Food: Leadership, Values and Social Control in a Massim Society, Cambridge, Cambridge University Press. 